\title{
Changes of Soil Physical Properties by Manured Sorghum Residues Incorporation
}

\author{
Ki-Yuol Jung*, Eul-Soo Yun, Chang-Young Park, Jae-Bok Hwang, Young-Dae Choi, and In-Seok Oh \\ Coarse Cereal Crop Research Division, NICS, RDA, Milyang, 627-830, Republic of Korea
}

(Received: September 27 2013, Accepted: October 14 2013)

\begin{abstract}
Although sorghum residue production was estimated to be $8 \sim 10 \mathrm{Mg} \mathrm{ha}^{-1}$, most sorghum straw was used to be burnt or removed after harvest. This experiment was conducted to evaluate the effect of the incorporation of manured sorghum residues on soil physical properties from 2010 to 2012 in the converted paddy field. Five treatment with 3 replication consisted of control, inorganic fertilizer (NPK), manured residues, sorghum stover and sawdust manure. The incorporation level of organic source was $10 \mathrm{Mg} \mathrm{ha}^{-1}$ without inorganic fertilizer NPK. The investigated physical parameters were bulk density (BD), porosity, water stability aggregate (WSA), water infiltration rater (WIR), penetration resistance (PR) and soil water retention characteristics (WRC) with soil depth. The incorporation of manured sorghum residues improved WIR significantly over inorganic fertilizer(NPK), sorghum residues and sawdust manure. The BD by incorporating with manured residues on sorghum was reduced significantly with crop residue over plot of NPK and sawdust. Significant increase in WSA was observed with stubble incorporation alone or manured sorghum residues. Soil WRC were significantly enhanced with manured sorghum residue incorporated without NPK. The average $P R$ at $0 \sim 15 \mathrm{~cm}$ was $0.54 \mathrm{MPa}$ for manured sorghum residues. For sawdust manure plot it was 0.42 MPa, for Sawdust manure plot 0.39 MPa and for NPK plot 0.54 MPa.
\end{abstract}

Key words: Sorghum residue, Incorporation, Physical properties

Comparison fo the physical properties of soils incorporated with NPK, sorghum redisue, sorghum manure and sawdust manure.

\begin{tabular}{|c|c|c|c|c|c|}
\hline Treatments & Bulk density & Porosity & Infitration rate & Water retenion & $\begin{array}{c}\text { Water stable } \\
\text { aggregate }\end{array}$ \\
\hline & $\mathrm{Mg} \mathrm{\textrm {m } ^ { - 3 }}$ & $\%$ & $\mathrm{~cm} \mathrm{hr}^{-1}$ & $\%$ & $\%$ \\
\hline Control & $1.35^{\mathrm{a}^{\dagger}}$ & $49.24^{\mathrm{c}}$ & $0.75^{\mathrm{d}}$ & $21.09^{\mathrm{b}}$ & $38.46^{\mathrm{c}}$ \\
\hline NPK & $1.31^{\mathrm{ab}}$ & $50.44^{\mathrm{b}}$ & $1.33^{\mathrm{d}}$ & $21.89^{\mathrm{b}}$ & $41.18^{\mathrm{bc}}$ \\
\hline Sorghum Residue & $1.23^{\mathrm{c}}$ & $53.59^{\mathrm{a}}$ & $3.91^{\mathrm{a}}$ & $22.88^{\mathrm{ab}}$ & $45.47^{\mathrm{b}}$ \\
\hline Sorghum manure & $1.20^{\mathrm{c}}$ & $54.83^{\mathrm{a}}$ & $3.30^{\mathrm{b}}$ & $24.67^{\mathrm{a}}$ & $48.70^{\mathrm{a}}$ \\
\hline Sawdust manure & $1.26^{\mathrm{bc}}$ & $52.55^{\mathrm{ab}}$ & $2.67^{\mathrm{c}}$ & $22.75^{\mathrm{b}}$ & $44.51^{\mathrm{b}}$ \\
\hline
\end{tabular}

Mean within a group followed by the same letter are not significantly different at probability $\mathrm{P}=0.05$ by duncan's multiple rang test.

\footnotetext{
*Corresponding author : Phone: +82553501263, Fax: +82553523059, Email: jungky@korea.kr

${ }^{\S}$ Acknowledgement: This Study was carried out with the support of "Study on Foothold Technology for Wet Injury Reducing of Upland Crops on Paddy Soils(project No PJ008723", Rural Development Administration Rupublic of korea.
} 


\section{Introduction}

농촌지역에서 발생하는 각종 바이오매스의 자원은 관리 되지 않고 농경지 주변에 방치해 두거나, 태우고 있는 실정 이며, 주변 환경에 부정적인 영향을 미치므로 이들 농업 부 산물의 토양환원은 환경보전 뿐만 아니라 친환경적 자연순 환의 효과를 얻을 수 있다. 세계적으로 식량작물의 바이오 매스의 발생량은 약 $2.85 \times 10^{10} \mathrm{Mg} \mathrm{yr}^{-1}$ 이 생산되고 있으 며, 양분 총량 (NPK 기준)을 환산하면 $81 \times 10^{6} \mathrm{Mg}$ 포함되 어 있고, 에너지로 환산하면 $1.86 \times 10^{9} \mathrm{~J}$ per Mg에 달하는 것으로 알려져 있다 (Rattan, 2008). 이러한 농업 부산물의 적절한 활용은 환경 부담을 줄이는 재활용이라는 측면뿐만 아니라 화학비료에 의존한 시비관리로 유기물함량이 낮은 농경지 토양의 유기물 보충과 함께 양분공급 및 근권환경을 개선할 수 있어 주목을 받고 있다 (Schertz and Bushnell, 1993). 최근 수수를 포함한 잡곡에 대한 소비자의 관심이 높 아지면서 재배면적이 크게 증가하고 있으나 수확 후 부산물 은 유기물자원으로 이용되지 못하고 있는 실정이다. 수수 부산물에는 N, P, K 성분함량이 각각 $0.8,0.1,1.0 \%$ 포함되 어 있어 보릿짚 $0.7,0.1,1.8 \%$, 볏짚 $0.7,0.1,1.5 \%$ 보다 질 소와 인산의 함량이 높아 유기물 자원으로 가치가 높은 것 으로 평가되고 있다 (Rattan, 2008). 수숫대의 건물 생산량 은 10a 당 800 1,000 kg 이상으로 높고 퇴비자원으로 활용 했을 때 수분 흡수율은 건물중의 4 배로 톱밥의 2.5 배 보다 높아 수분을 조절하는 역할이 우수하다. 또한, 수숫대의 탄 질률 $(\mathrm{C} / \mathrm{N}$ 율)은 48.5 로 톱밥 $(>100)$ 에 비해 낮고, 리그닌 함량도 톱밥 $(26 \sim 32)$ 에 비해 $15 \sim 17$ 로 낮아 분해되기가 쉽 다 (Bellakki et al., 1994). 수숫대를 돈분 퇴비화의 부재료 로 사용할 경우 톱밥퇴비와 비교하여 수분 흡수율이 높아 톱밥제조 비용을 절반수준으로 줄일 수 있어 유용한 퇴비자 원으로 활용 할 수가 있다. 수숫대 부산물을 토양에 환원하 면 화학비료에 비해 토양탄소 함량이 증가하여 토양의 투수 력이 증가하고 (Badanur, et al., 1990; Triplette, et al., 1968), 용적밀도가 낮아지며 (Bairathi, et al., 1974), 내수 성 입단 안정성이 증가된다고 보고하였다(Biswas, et al., 1971; Biswas, 1982). Bellakki 등(1994)은 ha당 5 톤의 수숫 대를 토양에 환원하여 시험을 수행한 결과 토양의 수분 보 유력이 화학비료에 비해 크게 증가하였다고 밝혔다. 또한 수수 부산물 환원 후 다시 수수를 재배하였을 때의 수수 수 량은 화학비료 처리구가 $1.75 \mathrm{Mg} \mathrm{ha}^{-1}$ 인 반면 수수 부산물
처리에 의해 $1.90 \mathrm{Mg} \mathrm{ha}^{-1}$ 로 크게 높아진다고 보고하였다.

우리나라에서는 1970년대부터 유기성 자원의 토양처리가 작물생산에 미치는 비료적 가치에만 초점을 맞추어 연구되 어 왔다. (Kim et al., 1999, Kwak et al., 2003). 토양에 있 어서 유기물 자원의 시용효과는 화학성 보다는 물리성 개선 효과에 주안점을 두고 있음에도 불구하고 유기물 자원별 토 양 물리성 개선효과에 대한 연구는 미진한 수준이다. 유기 물자원인 퇴비와 볏짚 등 농업 부산물과 채종유박, 맥주오 니 등의 산업 활동에서 나온 유기성 자원을 토양에 시용하 면 용적밀도와 경도를 낮추고 내수성 입단 및 통기성을 높 여 토양 물리성을 개선한다고 여러 연구자에 의해 밝혀졌다 (Jo. 1990, Hur et al., 1986; Park. 1978). Kim et. al. (2004)은 퇴비, 볏짚, 가축분뇨, 산업폐기물 등 유기자원을 토양에 시용하여 토양 물리성에 미치는 영향을 유기성 물질 종류 및 연용연수, 토양 특성, 토지이용 형태 등 조건을 고 려하여 시험을 수행한 결과 유기성 자원을 시용함에 따라 용적밀도 감소, 통기성 증가, 대공극 증가, 전단저항 감소 등 물리성 개선효과가 나타났다고 보고하였다.

따라서 본 연구는 유기질 자원으로서 가치가 높은 수수 부산물의 자연 순환형 관리기술을 개발하고 시용방법에 따 른 토양의 물리성 개선효과를 비교 분석하기위하여 2010년 부터 2012년까지 3년간 현지 시험하였다.

\section{Materials and Methods}

돈분 수수부산물 혼합 발효퇴비 제조 퇴비화를 위 하여 사용된 수수 부산물의 원료는 농촌진흥청 국립식량과 학원 기능성작물부 시험포장에서 수확 후 부산물을 수거하 여 사용하였으며, 톱밥은 목재소에서 생산된 톱밥을 사용하 였다. 수수 부산물은 수거 즉시 잔가지 파쇄기로 약 $5 \mathrm{~mm}$ 크기로 분쇄하여 사용하였다. 본 시험에 사용된 수수 부산 물의 화학적 특성은 Table 1 에서와 같이 질소 $1.35 \%$, 탄소 $42.8 \%$, 인산 $0.40 \%$, 칼륨 $1.0 \%$ 이었으며 톱밥은 질소 $0.06 \%$, 탄소 $52.2 \%$, 인산 $0.03 \%$, 칼륨 $0.26 \%$ 이었으며, 수 숫대의 탄질률 (C/N율)은 31:1로 톱밥 $920: 1$ 에 비해 월등히 낮은 특성을 보였다. 퇴비화는 건물중 기준으로 수수 부산 물과 톱밥 $100 \mathrm{~kg}$ 을 각각 고액 돈분과 혼합하였고 퇴비의 수분을 $50 \%$ 로 조절하였다.

퇴비화 방법은 수수부산물, 톱밥 및 돈분 혼합물을 약 1 $\mathrm{m}^{2}$ 규모의 보온용 플라스틱 Chamber를 이용하여 퇴비화를 실시하였으며, Chamber내 균일한 퇴비화를 위해 퇴비화과 정 전 기간 동안 5 회의 뒤집기 (각각 $7,14,21,28,35$ 일째) 를 행하였다. 또한 퇴비화 과정 동안 1 일 20 분간 1 회씩 강제 송풍을 실시하였다. 퇴비의 부숙화 온도를 측정하기 위해 온도측정 센서가 장착된 데이터로거 (WatchDog 100 series,

Table 1. Chemical properties of sorghum residues and sawdust used in this study.

\begin{tabular}{|c|c|c|c|c|c|}
\hline Resources & Nitrogen & Carbon & C/N Ratio & $\mathrm{P}_{2} \mathrm{O}_{5}$ & $\mathrm{~K}_{2} \mathrm{O}$ \\
\hline & \multicolumn{3}{|c|}{ - } & 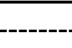 & --- \\
\hline Sorghum residue & 1.35 & 42.8 & $31: 1$ & 0.40 & 1.00 \\
\hline Sawdust & 0.06 & 55.2 & $920: 1$ & 0.03 & 0.26 \\
\hline
\end{tabular}


Table 2. Physico-chemical properties of soil before field experiment.

\begin{tabular}{|c|c|c|c|c|c|c|c|c|c|c|c|}
\hline \multirow{2}{*}{$\mathrm{pH}$} & \multirow{2}{*}{$\mathrm{EC}$} & \multirow{2}{*}{$\mathrm{T}-\mathrm{N}$} & \multirow{2}{*}{ O.M. } & \multirow{2}{*}{$\begin{array}{l}\text { Avail. } \\
\mathrm{P}_{2} \mathrm{O}_{5}\end{array}$} & \multicolumn{3}{|c|}{ Exch. cation } & \multicolumn{3}{|c|}{ Particle size } & \multirow{2}{*}{$\begin{array}{c}\text { Textural } \\
\text { Class }\end{array}$} \\
\hline & & & & & K & $\mathrm{Ca}$ & $\mathrm{Mg}$ & Sand & Silt & Clay & \\
\hline$(1: 5)$ & $\mathrm{dS} \mathrm{m}^{-1}$ & $\%$ & $\mathrm{~g} \mathrm{~kg}^{-1}$ & $\mathrm{mg} \mathrm{kg}{ }^{-1}$ & ------- & holc $\mathrm{k}$ & 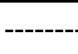 & - & $(\%)$ & ------ & \\
\hline 6.82 & 0.25 & 0.20 & 21.9 & 102.7 & 0.46 & 7.08 & 1.79 & 31.7 & 51.1 & 17.2 & Silty loam \\
\hline
\end{tabular}

Spectrum, Inc.)를 퇴비더미 중간 부위에 설치하여 한 시간 단위로 온도를 측정하였다. 시료는 퇴적물 더미의 중간 깊 이에서 채취하였고, Wood chip은 수작업으로 선별하여 제 거하였다. 퇴비 수분 함량 측정을 위한 시료는 채취 후 분석 전까지 $-20^{\circ} \mathrm{C}$ 에 냉동 보관하였으며, 화학 분석을 위한 시 료는 음지에서 풍건한 후 $0.5 \mathrm{~mm}$ 체를 통과할 수 있도록 분 쇄하여 분석시료로 이용하였다.

시험토양 및 처리 본 시험은 농촌진흥청 국립식량과 학원 기능성작물부내에 소재한 시험포장에서 수행하였으며 토양특성은 홍적층을 모재로 한 토양으로 식질계 적황색토 로 덕평통 (fine, mesic family of Typic Hapludults)으로 2009년 밭으로 전환한 토양이었다. 시험 포장의 이화학적 특성은 Table 2 에서와 같이 모래 $31.7 \%$, 미사 $51.1 \%$, 점토 $17.2 \%$ 의 미사질양토로 $\mathrm{pH}$ 6.82는 중성으로 생육에 적합한 범위에 있었으며, 유기물함량도 $21.9 \mathrm{~g} \mathrm{~kg}^{-1}$ 로 적정범위 (20 30 g kg$)^{-1}$ )내에 있었으며, 유효인산은 $102.7 \mathrm{mg} \mathrm{kg}^{-1}$ 이 었다.

처리내용은 무비구, 화학비료 처리구 $(\mathrm{NPK})$, 돈분 수수 부산물 혼합 발효퇴비 처리구(이하 수수 부산물 퇴비 처리 구), 수수 부산물 환원 처리구, 돈분 톱밥 혼합 발효퇴비 처 리구 (이하 톱밥퇴비 처리구) 등 5 개 수준으로 난괴법 (Randomized complete block design, RCBD) 3반복으로 수 행하였다. 수수 부산물, 수수 부산물 퇴비 및 톱밥퇴비는 파 종 30 일 전에 화학비료 없이 각각 $10 \mathrm{Mg} \mathrm{ha}$ 을 시용하였 고, 화학비료 $(\mathrm{NPK})$ 는 파종 전에 질소, 인산과 칼리 비료를 각각 $100 \mathrm{~kg} \mathrm{ha}^{-1}, 70 \mathrm{~kg} \mathrm{ha}{ }^{-1}$ 과 $80 \mathrm{~kg} \mathrm{ha}^{-1}$ 전량 기비로 시 용하였다.

재배방법 시험 작물은 강원도농업기술원에서 육성한 황금찰수수 (Hwanggeumchalsusu)를 공시하여 수행하였다. 재배법은 처리 후 휴립복토기를 이용하여 폭 $60 \mathrm{~cm}$ 의 두둑 을 짓고 동시에 주간간격 $20 \mathrm{~cm}$ 에 구멍크기 $5 \mathrm{~cm}$ 크기로 천공된 흑색유공비닐을 피복하고 6 월 15 일에 파종하였고, 유묘가 정착한 후 1 주 1 본을 남기고 솎음을 하였다. 수량조 사 조사는 농촌진흥청 농업과학기술 연구조사분석기준 (농 촌진흥청, 2012)에 의해 생육이 일정한 지점에서 3반복 예 취한 다음 ha당 수량으로 환산하였다.

물리성 분석 수수 부산물 퇴비시용시 토양의 물리적 특성 변화에 미치는 영향을 평가하기 위해 무비구, 화학비 료 처리구 (NPK), 수수 부산물퇴비 처리구, 수수부산물 환 원 처리구, 톱밥퇴비 처리구 등 5 개 수준으로 처리하여 시 험 3 년차 수수 수확 후에 조사하였다. 토양 물리성 분석은 용적밀도, 포화수리전도도, 원추관입저항, 보수력, 내수성
입단 등을 분석하였다. 용적밀도 $(\mathrm{BD})$, 고상 $(\mathrm{Vs})$, 액상 $(\mathrm{Vw})$ 등은 직경 $5 \times 30 \mathrm{~cm}$ 실린더 코어 (Cylinder Core)를 이용하여 수수 수확 후 처리방법 별로 3 반복 채취하여 $5 \mathrm{~cm}$ 길이로 절단하여 토양을 $105^{\circ} \mathrm{C}$ 에서 24 시간 건조시켜 흡착 된 수분을 제거한 후 건조토양의 무게를 대상으로 고체가 차지하는 부피를 고상 $(\mathrm{Vs})$, 물이 차지하는 부피를 액상 $(\mathrm{Vw}), 100 \%$ 에서 액상과 고상을 제한 값을 기상 $(\mathrm{Va})$ 으로 하 여 계산하였으며, 토양 및 식물체분석법 (NIAST, 2000)에 준하여 분석하였다. 또한 토성분석은 미농무성의 피펫분석 법 (USDA, 1996)을 기준으로 분석하였으며, 원추관입저항 은 관입식 저항측정계 (Penetrolgger art. NR)를 이용하여 처리별로 10 반복 조사하였다. 내수성입단은 지름 $2 \sim 4$ $\mathrm{mm}$ 풍건 입단을 이용하여 내수성 입단분석기(Eijkelkamp, Wet sievingart. NR)를 이용하여 분석하였다. 토양의 투수 력은 내경 $30 \mathrm{~cm}$, 외경 $55 \mathrm{~cm}$, 높이 $25 \mathrm{~cm}$ 인 금속원판으로 된 Double ring method (Black, 1965)로 측정하였고, 단위 면적, 단위 시간에 토양에 침투하는 물의 량을 측정하여 Darcy's 법칙 (1856)에 따라 계산하였다.

\section{Results and Discussion}

수수 부산물 및 톱밥퇴비의 특성 퇴비더미의 온도변 화는 미생물의 대사활성을 반영하고 퇴비화 진행정도를 나 타내는 중요한 척도이며 (Finstein and Morris, 1975; Miller, 1991), 부숙화 정도를 예측하는데 있어 매우 간편하 면서도 유용한 수단으로 이용되고 있고 (Jimenez and Garcia, 1989). 퇴적더미의 퇴비화 과정 중 이러한 특징적인 온도변화는 퇴비의 부숙도를 예측하는데 있어 매우 간편하 면서도 유용한 수단으로 이용이 가능하다 (Jimenez and

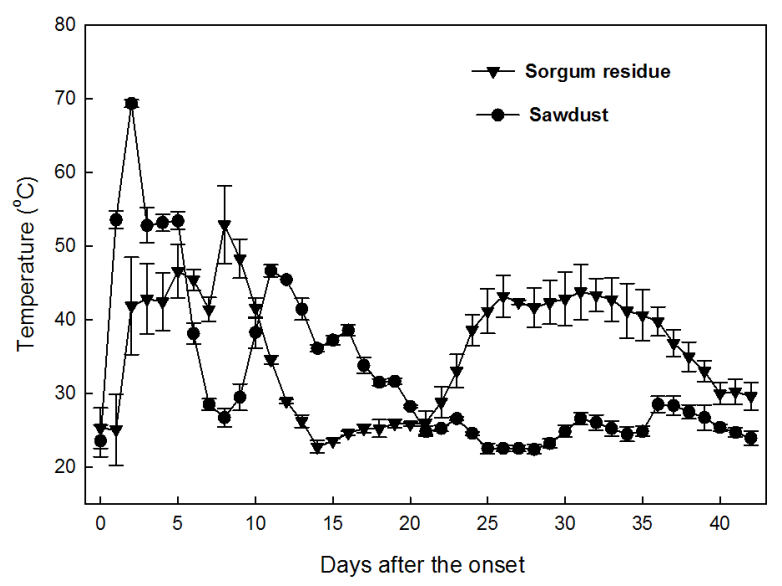

Fig. 1. Changes of temperature compost pile during composting process. 
Garcia, 1989). 수수 부산물 및 톱밥 퇴비화 과정의 온도변 화를 측정한 결과는 Fig. 1에서 보는 바와 같다.

수수 부산물 및 톱밥퇴비는 퇴비화 처리 직후 온도가 상승 하기 시작하여 약 5 일을 전후하여 $60^{\circ} \mathrm{C}$ 이상까지 상승하였으 며, 약 10 일 동안 $50 \sim 60^{\circ} \mathrm{C}$ 이상 고온을 유지하였다. 톱밥퇴 비가 수수부산물 퇴비에 비해 퇴비화 과정 중 온도상승이 빨 랐으며 처리 후 약 5 일 후 $70^{\circ} \mathrm{C}$ 이상까지 상승한 반면 수수 부산물 퇴비는 처리 후 약 9 일경에 최고온도에 도달하였다. 이는 수수 부산물 퇴비가 조직이 거칠고 통기가 잘되기 때문 에 톱밥퇴비에 비해 온도가 낮고 서서히 상승하는 것으로 판 단되었다. 또한 수수 부산물 퇴비는 처리 9일 후 최고온도에 도달하였다가 온도가 낮아지는 반면, 톱밥퇴비는 처리 후 약 15 일 후 온도가 낮아지는 경향을 보였다. 수수 부산물 퇴비 와 톱밥퇴비 모두 3 차 뒤집기 직후인 21 일을 전후로 $30^{\circ} \mathrm{C}$ 미 만으로 온도가 감소되어 1 차 발효에 도달하였다. 이는 퇴비 화 초기 퇴적더미 중에는 미생물에 의해 분해가 용이한 탄수 화물, 지방질 및 아미노산류가 풍부하므로 온도는 급격하게 상승하고 이후 분해가 용이한 이들 물질들이 고갈되고, 상대 적으로 난분해성 물질들만 남게 되어 미생물 활성이 감소되 기 때문으로 판단된다 (The composting council, 1993). 3차 뒤집기 이후 수수 부산물퇴비는 다시 온도가 상승하여 처리 후 35 일 까지 약 10 일간 $40^{\circ} \mathrm{C}$ 이상 고온이 유지되었다. 이는 수수 부산물 퇴비가 1차 발효 이후 조직의 밀도가 낮아져 온 도상승이 높아진 결과로 판단되었다. 반면 톱밥퇴비는 수수 부산물 퇴비에 비해 2 차 발효기간 중 온도상승이 낮은 경향 을 보였다. 이러한 결과로 볼 때 돈분액비와 혼합하여 퇴비 화 할 경우 수수 부산물 퇴비는 톱밥퇴비에 비해 10 일 빠른 35 일이 걸려 퇴비화 기간을 크게 단축할 수가 있다.

퇴비화 후 수수 부산물 퇴비와 톱밥퇴비의 화학적 특성을 조사한 결과는 Table 3 과 같았다. 수수 부산물 퇴비의 탄소 와 질소 함량은 각각 $41.07,2.01 \%$ 로 조사되었고, 작물 생육 에 필요한 인산과 칼리의 함량은 증가되는 경향을 나타내었
다. 인산 $0.97 \%$, 칼륨, 칼슘과 고토 함량은 각각 $3.41,0.70$, $0.35 \%$ 로 나타났다. 이는 퇴비화 전 부산물에 비해 질소 함량 은 약 1.5 배 높아지는 경향을 나타내었고, 탄소 함량은 낮아 지는 경향을 보였으며 인산은 2.5 배, 칼륨은 약 3.4 배 높았 다. 반면 톱밥퇴비는 질소함량이 38 배 높아졌고, 탄소함량은 약 1.6 배 낮아지는 경향을 보였다. 인산의 함량은 97 배, 칼륨 은 12 배 높아졌다.

탄질율은 전통적으로 퇴비의 부숙도와 품질을 판정하는 주요 인자로 이용되어 왔다(Morel et al., 1985). 다수의 연 구자들은 탄질율이 20 이하일 때 퇴비의 완숙점에 도달한 것으로 보고했다 (Cardenas and Wang, 1980; Golueke, 1972). 그러나 리그닌과 같은 난분해성 유기물 분획이 높은 물질의 경우는 종종 20 이상의 탄질율에서도 퇴비가 완숙되 는 것으로 나타났다 (Regan and Jeris, 1970).

수수 부산물 퇴비는 발효 후 약 3 개월 간 후숙과정을 거 치면 부피는 약 $30 \%$ 감소하고 유기물은 $30 \sim 40 \%$ 가 분해되 어 탄질률은 각각 42.8 에서 20.4로 감소하고, 전 질소 함량 은 $1.35 \%$ 에서 $2.01 \%$ 높아졌다.

\section{수수 부산물 퇴비 시용에 따른 물리성 개선 효과}

토양 환경개선 효과를 평가하는 방법으로는 토양구조, 토양 층위 분화, 층위의 두께, 토색, 투수성, 입단, 토양경도 등 이 있으며, 유기물 시용으로 토양환경이 개선되어 작물의 생산성이 증가한다고 알려져 있다 (Bellakki et al., 1994; Zucker and Brown, 1998). 수수 부산물 처리에 따른 작토 층 $(10 \sim 20 \mathrm{~cm})$ 의 용적밀도, 삼상분포, 공극률 등의 특성은 Table 4에서와 같다. 공극률은 유기물 처리구 (수수 부산물 환원 처리구, 톱밥퇴비 처리구)에서 무비구와 화학비료 처 리구 (NPK)에 비해 수분함량이 낮아 통기성이 증가하는 것 으로 나타났다. 또한 공극률은 화학비료 처리구 (NPK)에 비 해 수수 부산물 퇴비 처리구 $8.7 \%$, 수수 부산물 환원 처리 구 $6.2 \%$, 톱밥퇴비 처리구 $4.2 \%$ 정도 증가하는 것으로 나타

Table 3. Chemical properties of used sorghum residues manure and sawdust manure.

\begin{tabular}{|c|c|c|c|c|c|c|c|}
\hline Resources & Nitrogen & Carbon & C/N Ratio & $\mathrm{P}_{2} \mathrm{O} 5$ & $\mathrm{~K}_{2} \mathrm{O}$ & $\mathrm{CaO}$ & $\mathrm{MgO}$ \\
\hline \multicolumn{8}{|c|}{ 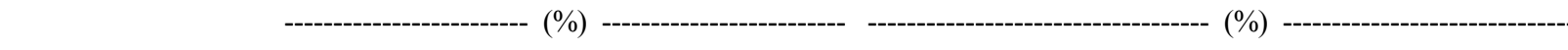 } \\
\hline Sorghum residue & 0.94 & 43.17 & 45.9 & 0.41 & 1.90 & 0.46 & 0.23 \\
\hline Sorghum manure & 2.01 & 41.07 & 20.4 & 0.97 & 3.41 & 0.70 & 0.35 \\
\hline Sawdust manure & 2.31 & 34.10 & 14.7 & 2.92 & 3.20 & 5.30 & 1.14 \\
\hline
\end{tabular}

Table 4. Comparison of the physical properties of soils incorporated with NPK, sorghum residue, sorghum manure and sawdust manure.

\begin{tabular}{lccccc}
\hline \hline \multirow{2}{*}{ Treatments } & Bulk & \multicolumn{3}{c}{ Three phases } & \multirow{2}{*}{ Porosity } \\
\cline { 2 - 4 } & density & Solid & Liquid & Gaseous & \\
\cline { 3 - 4 } Control & Mg m $^{-3}$ & $-30.76 \mathrm{a}$ & $27.33 \mathrm{a}$ & $21.91 \mathrm{a}$ & $49.24 \mathrm{c}$ \\
NPK & $1.35 \mathrm{a}$ & $49.56 \mathrm{ab}$ & $27.46 \mathrm{a}$ & $22.97 \mathrm{a}$ & $50.44 \mathrm{bc}$ \\
Sorghum residue & $1.31 \mathrm{ab}$ & $46.41 \mathrm{c}$ & $28.49 \mathrm{a}$ & $25.10 \mathrm{a}$ & $53.59 \mathrm{a}$ \\
Sorghum manure & $1.23 \mathrm{c}$ & $45.17 \mathrm{c}$ & $29.59 \mathrm{a}$ & $25.24 \mathrm{a}$ & $54.83 \mathrm{a}$ \\
Sawdust manure & $1.20 \mathrm{c}$ & $47.45 \mathrm{bc}$ & $30.25 \mathrm{a}$ & $22.30 \mathrm{a}$ & $52.55 \mathrm{ab}$ \\
\hline
\end{tabular}



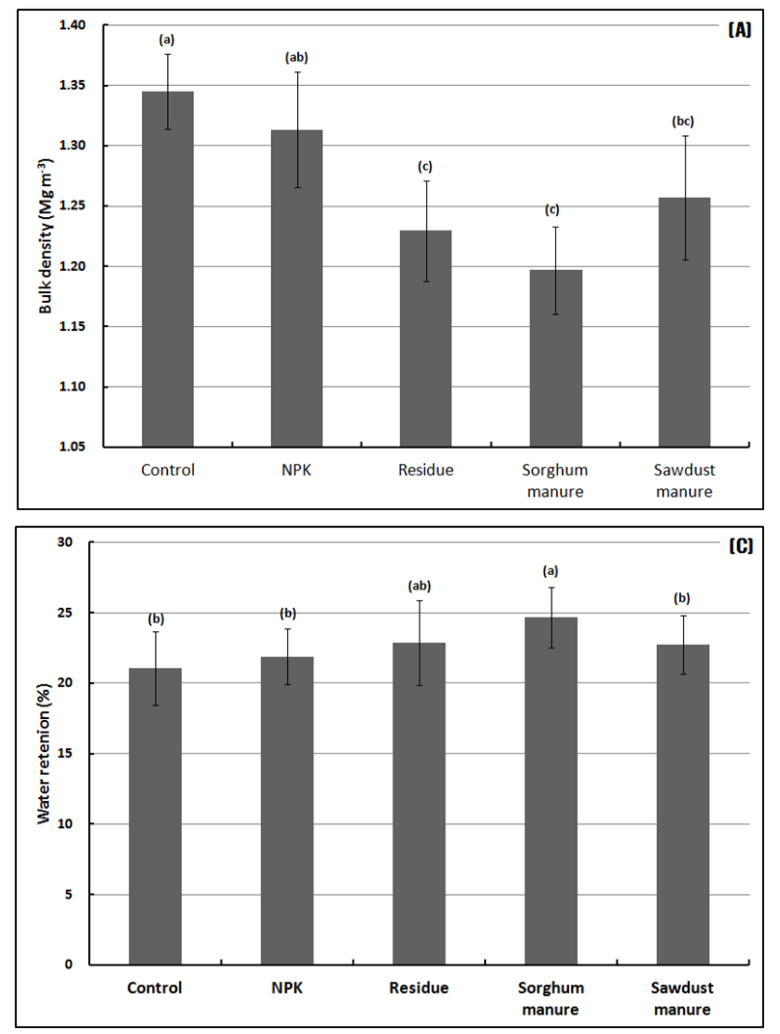
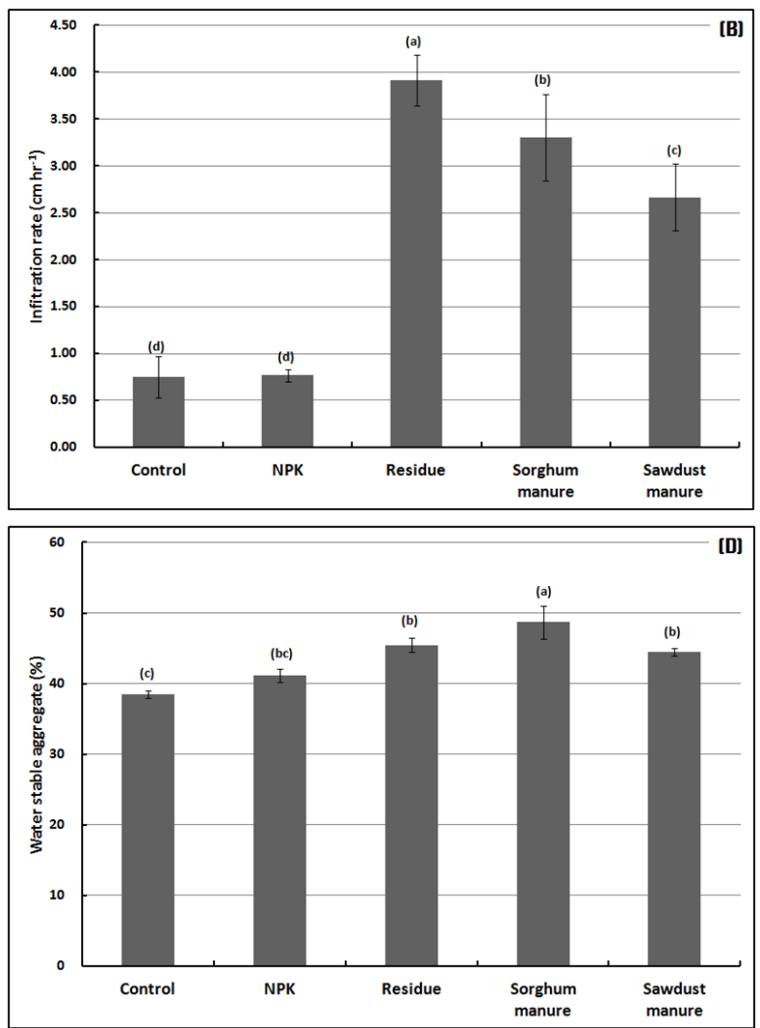

Fig. 2. Comparison of the physical properties of soils incorporated with NPK, sorghum residue, sorghum manure and sawdust manure; (A) Bulk density; (B) Infiltration rate; (C) Water retention; (D) Water stable aggregate.

났다. 톱밥퇴비 처리구의 수분함량이 $30.3 \%$ 내외로 높은 반 면 수수 부산물 퇴비 처리구는 $29.5 \%$ 로 낮은 경향을 보였 다. 또한 기상은 액상과 정반대로 양상을 보였는데 톱밥퇴 비 처리구의 기상은 $22.3 \%$ 내외로 수수 부산물 퇴비 처리구 $25.2 \%$ 보다 상대적으로 월등히 낮아 공극률이 감소하는 것 으로 나타났다. 수수 부산물 퇴비 처리구의 용적밀도는 $1.20 \mathrm{Mg} \mathrm{m}^{-3}$ 으로 화학비료 처리구 (NPK) $1.31 \mathrm{Mg} \mathrm{m}^{-3}$, 톱 밥퇴비 처리구 $1.26 \mathrm{Mg} \mathrm{m}^{-3}$ 비해 감소하는 경향을 보였다. 특히, 유기성 물질의 종류에 따라 차이가 존재 했는데 수수 부산물 퇴비 처리구가 수수 부산물 환원 처리구와 톱밥퇴비 처리구에 비해 물리성 개선효과가 높은 경향을 보였다. 이 러한 결과는 Badanur et al. (1990)과 Bairathi et al. (1974) 이 수수 부산물의 토양환원에 의해 토양의 용적밀도가 감소 한다는 보고와 유사한 결과를 보였다.

수수 부산물 퇴비 시용에 따른 투수력, 보수력, 내수성입 단 등 토양 물리성 개선효과는 Fig. 2에서와 같다.

투수력은 수수 부산물 환원 처리구가 무비와 화학비료 처리구 (NPK)에 비해 크게 높아지는 경향을 보였으며, 부산 물퇴비 처리구와 톱밥퇴비 처리구에 비해서도 높은 결과를 보였다. 이는 수수 부산물환원으로 토양의 공극률 증가에 기인한 것으로 판단되었다. 이러한 결과는 Triplette et al. (1968)이 수수 부산물의 토양에 환원하면 화학비료 보다 토 양의 투수력이 증가한다는 연구결과와 일치하였다.

수수 부산물 퇴비 시용에 따른 보수력은 화학비료 처리 구 (NPK)에 비해 수수 부산물 퇴비 처리구가 $12.7 \%$, 톱밥퇴 비 처리구가 $3.9 \%$, 수수 부산물 환원 처리구가 $4.5 \%$ 증가하
는 것으로 나타났으며, 수수 부산물 환원 처리구와는 차이 는 존재하였지만 통계적 유의성은 없었다. Badanur et al. (1990)은 수수 부산물 시용이 토양의 보수력을 크게 증가시 킨다고 하였으며, Unger (1976)는 토양에 수수부산물을 매 년 $5 \mathrm{t} \mathrm{ha}{ }^{-1}$ 을 시용하면 화학비료에 비해 보수력이 증가한다 고 보고하였다. 또한 Verma and Sngh (1974)은 밀짚을 토 양에 시용하여 시험한 결과 화학비료에 비해 보수력이 크게 증가한다고 보고하였다. 이러한 결과는 수수 부산물 시용으 로 토양의 유기물 함량이 증가하여 보수력이 높아진 결과로 판단되었다.

수수 부산물 처리에 따른 $1 \mathrm{~mm}$ 이상의 내수성 입단은 화 학비료 처리구 (NPK)에 비해 부산물 퇴비 처리구가 $18.2 \%$ 로 가장 높았으며, 수수 부산물 환원 처리구와 톱밥퇴비 처 리구가 각각 $10.4 \%, 8.0 \%$ 이상 증가 되는 것으로 나타났다.

토양강도는 수분이동과 작물의 뿌리 신장에 영향을 미쳐 생산량의 차이를 가져 오는 영농에 있어 중요한 역할을 하 는 토양 물리성의 중요한 요소이다. Jo et al. (1997)에 의하 면 토양의 경도는 토성과 용적밀도, 수분함량에 따라 항상 변화되며, 작물 뿌리의 생육은 $15 \sim 20 \mathrm{~kg} \mathrm{~cm}^{-3}$ (2.0 MPa) 이상이 되면 뿌리신장이 장애를 받는다고 하였다. 또한 Hamza and Anderson (2005)에 의하면 토양 경반층 생성은 토양에서 용적밀도 증가와 공극률 감소, 수분이동 및 통기 성을 저해하고 결국 작물 뿌리신장을 저해하여 수확량 감소 의 원인이 된다고 하였다.

수수 부산물 처리에 따른 원추관입저항을 조사한 결과는 Fig. 3에서와 같다. 수수 부산물 등 유기물 처리에 의해 토 


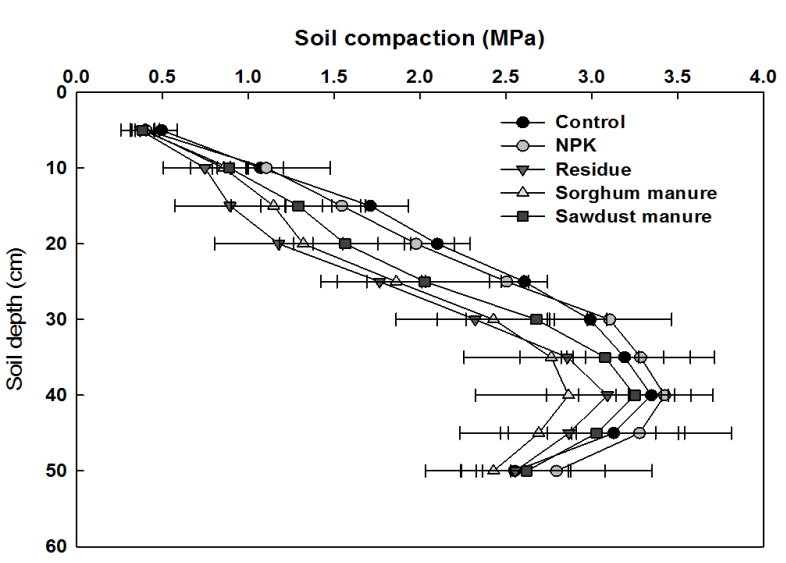

Fig. 3. Changes of soil penetration resistance with incorporation of NPK, sorghum residue, sorghum manure and sawdust manure at different soil depth.

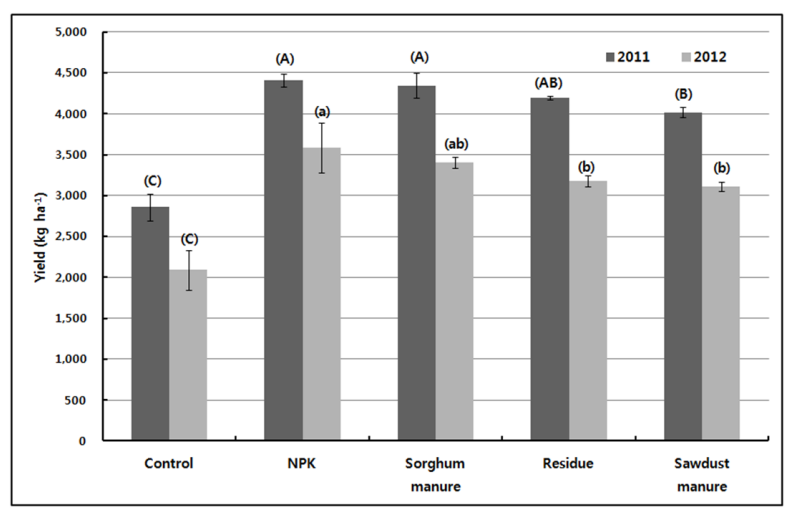

Fig. 4. Yield responses to incorporation of NPK, sorghum residue, sorghum manure and sawdust manure.

양의 강도가 크게 낮아지는 결과를 보였으며, 화학비료 (NPK), 톱밥퇴비, 수수 부산물 퇴비, 수수 부산물 환원 처 리구 순으로 낮아지는 경향을 보였다. 표토 층 $(0 \sim 10 \mathrm{~cm})$ 과 심토 $(50 \mathrm{~cm}$ 이상) 에서는 처리 간에 토양강도의 차이가 적 었으나, 작토층 $(10 \sim 40 \mathrm{~cm})$ 까지는 처리 간에 뚜렷한 차이 를 보였다. 토양 $20 \mathrm{~cm}$ 깊이에서의 토양강도를 비교하면 화 학비료 (NPK) 처리구 $1.98 \mathrm{MPa}$ 에 비해 톱밥퇴비 $1.56 \mathrm{MPa}$, 수수 부산물 퇴비 $1.32 \mathrm{MPa}$, 수수 부산물 환원 처리구 1.18 $\mathrm{MPa}$ 로 강도가 급격하게 낮아지는 경향을 보였다. 이러한 결과는 수수 부산물 환원에 의해 상대적으로 용적밀도, 고 상, 공극률, 함수율, 액상, 기상 등의 물리성이 개선된 결과 로 보였다. 따라서 수수 부산물 토양환원이 토양의 강도를 크게 낮추어 토양의 물리성 개선효과가 높을 것으로 판단되 었다.

수수의 수량성 수수 부산물의 토양 환원 방법에 따른 수수 (Sorghum bicolor L.)의 수량성을 조사한 결과는 Fig 4 와 같았다. 수수의 수량성은 화학비료 (NPK) 처리구에서 가장 높았으며, 수수 부산물퇴비 처리구, 수수 부산물 환원 처리구, 톱밥퇴비 처리구 순으로 수량 반응을 보였다. 특히 수수 부산물퇴비 처리구는 화학비료 (NPK) 처리구에 비해
수량이 다소 낮았으나 유의적인 차이가 없는 것으로 나타났 다. 따라서 이러한 결과로 볼 때 수수 부산물을 토양에 환원 시 퇴비화하여 환원하는 것이 수수의 생육에 효과가 있는 것으로 판단되었다.

\section{Conclusions}

유기질 자원으로서 가치가 높은 수수 부산물의 효율적인 환원기술을 개발하고 토양의 질 향상을 통한 고품질 농산물 을 생산하기 위한 자연 순환형 관리기술을 개발하기 위하여 수수 부산물의 퇴비화 특성과 수수 부산물 발효퇴비의 시용 에 따른 토양의 물리적 특성변화를 비교 분석한 결과 다음 과 같은 결론을 얻었다.

수수 부산물과 돈분을 70:30 wt/wt 혼합하여 퇴비화 한 결과 톱밥퇴비에 비해 퇴비화 처리 약 5 일 후 $60^{\circ} \mathrm{C}$ 이상까지 상승하였으며, 처리 후 35 일 까지 약 10 일간 $40^{\circ} \mathrm{C}$ 이상 고 온이 유지되었고 톱밥퇴비에 비해 10 일 빠른 35 일이 걸려 퇴비화 기간을 크게 단축할 수가 있었다. 수수 부산물퇴비 처리구의 탄소와 질소 함량은 각각 $41.07,2.01 \%$ 이었고, 인 산 $0.99 \%$, 칼리, 칼슘과 고토 함량은 각각 $3.41,0.70$, $0.35 \%$ 으로 톱밥퇴비에 비해 높았다.

수수 부산물 퇴비 시용에 따른 용적밀도는 $1.20 \mathrm{Mg} \mathrm{m}^{-3}$ 으로 화학비료 (NPK) $1.31 \mathrm{Mg} \mathrm{m}^{-3}$, 톱밥퇴비 $1.26 \mathrm{Mg} \mathrm{m}^{-3}$ 에 비해 낮았으며, 공극률은 화학비료 (NPK), 수수 부산물 환원, 톱밥퇴비에 비해 각각 $8.7 \%, 6.2 \%, 4.2 \%$ 증가하였다.

보수력은 화학비료 (NPK)에 비해 수수 부산물 퇴비 처리 구가 $12.7 \%$, 톱밥퇴비 처리구가 $3.9 \%$, 수수 부산물 환원 처 리구가 $4.5 \%$ 증가하였다.

내수성 입단은 화학비료 처리구 $(\mathrm{NPK})$ 에 비해 부산물 퇴 비 처리구가 $18.2 \%$ 로 가장 높았으며, 수수 부산물 환원 처 리구와 톱밥퇴비 처리구가 각각 $10.4 \%, 8.0 \%$ 이상 증가 되 었다. 토양강도는 화학비료 $(\mathrm{NPK})$ 처리구 $1.98 \mathrm{MPa}$ 에 비해 톱밥퇴비 $1.56 \mathrm{MPa}$, 수수 부산물 퇴비 $1.32 \mathrm{MPa}$, 수수 부산 물 환원 처리구 $1.18 \mathrm{MPa}$ 로 순으로 낮았다. 수수 부산물 퇴 비 시용에 따른 수수의 수량은 화학비료 (NPK)에 비해 약 $10 \%$ 정도 낮았으나 통계적 유의성이 없었으며, 부산물 환원 과 톱밥퇴비에 비해 각각 $7.1 \%, 9.5 \%$ 증수되었다.

결론적으로 수숫대 발효퇴비는 수수 부산물 환원과 톱밥 퇴비에 비해 토양 물리적 개선효과가 높았으며. 유기물 자 원으로써 재활용이 가능하였으며, 작물 생산성을 고려한다 면 수수대의 퇴비화 과정을 거친 후 사용하는 것이 더 좋은 재활용 방안으로 평가되었다.

\section{References}

Badanur, V.P., C.M. Poleshi, and B.K. Naik. 1990. Remove from marked Records Effect of organic matter on crop yield and physical and chemical properties of a Vertisol. J. Ind. Soc. Soil Sci. 38(3): 417-420.

Bairathi, R.C., M.M. Guppta, and S.P. Seth. 1974. Effect of different legume crop residue on soil properties, yield and nutrient uptake by succeeding wheat crop. Journal of the 
Indian Society of Soil Science, 22(4): 304-307.

Bellakki, M.A. and V.P. Badanur. 1994. Effect of Residue incoporation on ohysicai and chemical properties of a vertisoil and yield of sorghum. J. Ind. Soc. Soil Sci. 42(4): 533-535.

Biswas, T.D. 1982. Management of soil physical conditions for soil productivity. J. Indian Soc. Soil Sci. 30: 427-439.

Biswas, T.D., B.L. Jain, and S.C. Mandal. 1971. Cumulative effect of different levels of manures on the physical properties of soil. J Indian Soc. Soil Sci. 19(1): 31-37.

Black, C.A. 1965. Methods of soil analysis, Part I . Am. Soc. Agron, Medison, USA.

Cardenas, R.R. and L.K. Wang. 1980. Composting process. In Handbook of environmental Engineering, vol. II. The Human Press, New York, pp. 269-327.

Darcy, H. 1856. Les Fontaines Publiques de la Ville de Dijon, Dalmont, Paris.

Finstein, A.S. and M.L. Morris. 1975. Microbiology of municipal solid waste composting. adv. Appl. Microbiol. 19: 113-151.

Golueke, C.G. 1972. Composting; A study of the process and its priciples. Rodale Press. p.13-15.

Hamza, M.A., and W.K. Anderson. 2005. Soil compaction in cropping systems. A review of the nature, causes and possible solutions. Soil Tillage Res. 82(2):121-145.

Jimenez, E.I. and V.P. Garcia. 1989. Evaluation of city refuse compost maturity: review. Biological Wastesw. 271: 115-142.

Jo, I.S. 1990. Effect of organic fertilizer on soil physical properties and plant growth. Technical Bulletin No. 119. p.1-16. Food \& Fertilizer Technology Center. Suwon, Korea. Jo, I.S., B.K. Hyun, H.J. Cho, Y.S. Jang, and J.S. Shin. 1997. Effect of soil texture and bulk density on the least-limiting water range. Korean J. Soil Sci. Fert. 44(1): 51-55.

Kim, L.Y., H.J. Jo, and K.H. Han. 2004. Changes of physical properties of soil by organic material application in farm land. Korean J. Soil Sci. Fert. 37(5): 704-710.

Kim, J.G., K.B. Lee, S.B. Lee, D.B. Lee, and S.J. Kim. 1999. The effect of long-term application of different organic materrial sources on chemical properties of upland soil. Korean J. Soil Sci. Fert. 32(3): 239-253.

Kwak, H.K., K.I. Seong, N.J. Lee, S.B. Lee, M.S. Han, and K.A. Roh. 2003. Changes in chemical properties and fauna of plastic film house soil by application of chemical fertilizer and composted pig manure. Korean J. Soil Sci. Fert. 36(5): 304-310.

Miller, F.C. 1991. Biodegradation of solid waste by composting. In Martin, A.M. (ed) Biology degradation of wastes. Elsevier Applied Science, London. p.1-30.

Morel, J.L., F. Colin, J.C. Germon, P. Godin, and C. Juste. 1985. Methods for the evaluation of maturity of municipal refuse compost. In Gaser, J.KR. (ed) Composting of agricultural and other wastes. Elsevier Applied Science Publishers. London, and N.Y. p.56-72.

NIAST. 2000. Methods of soil chemical analysis. National Institute of Agricultural Science and Technology, RDA, Suwon, Korea.

Park, C.S. 1978. Effect of organic material application on the growth and yield of crops in Korea. Korean J. Soil Sci. Fert. 11: 175-194.

Rattan, L. 2008. Crop residue and soil carbon. The Ohio State University, Columbus, OH 43210 USA. Carbon Management and Sequestration Center.

Regan, R.W. and J.S. Jeris. 1970. A review of decomposting of cellulose and refuse. Compost Science. 11(1): 17-20.

Schertz, D.L. and J.L. Bushnell. 1993. USDA, crop residue management action plan. Journal of Soil and Water Conservation, 48(3): 175-177.

The composting council. 1993. Composting facility operating guide. The composting council. Alexandria, Verginia.

Triplette, Jr., G.B., D.M. Van Doren, Jr., and B.L. Schmidt. 1968. Effect of corn (Zea mays L.) stover much on no-tillage corn yield and water infiltration. Agronomy Journal. 60: 236-239.

Unger, P.W. 1976. Surface residue, water application, and soil texture effects on water accumulation. Soil Sci. Soc. Am. J., 40: 298-300.

USDA. 1996. Soil Survey Laboratory Methods Manual. soil survey investions report No. 42 version 3.0.

Verma, S.M. and N.T. Singh. 1974. Effect of some indigenous organic materials on soil aggregation. J. Indian Soc. Soil Sci. 22(3): 220-225.

Zucker, L.A. and L.C. Brown(Eds). 1998. Agricultural drainage: Water quality impacts and subsurface drainage studies in the Midwest, The Ohio State University Extension Bulletin 871. The Ohio State University, Columbus, Ohio. 